\title{
What's in a People? Social Facts, Individual Choice, and the European Union
}

\author{
Dimitry Kochenov
}

Joining the majority of other contributors to this forum I fully support the useful and timely initiative for national voting rights for EU citizens, which has been overdue.

My argument builds around well-known but much ignored effects of the European integration project on the member states and their societies which require adjusting our understanding of who is a foreigner in today's Europe, i.e. what is a 'people' in the context of the European project. Given the wording of Article $25 \mathrm{TFEU}$, which allows the Commission to propose additional rights of EU citizenship but requires unanimity in the Council and approval by the member states, the change will not be easy. However, this would be a bad reason for not trying.

Should it not be up to the individual to decide who will participate in political life rather than up to the state with its random naturalisation procedures and nonsensical tests created to divide societies instead of uniting them? ${ }^{1}$ Hailing from a totalitarian regime myself I cannot overstate the value of being left alone, free from the state's critique, endorsements, or ideas about 'good life'. The criterion of genuine ties that Bauböck preaches in his contribution to the present debate starts from the presumption of people's inability to take responsible decisions for themselves whether they have such ties or not, superimposing thus their judgement with a state-mandated one. Given that those who do not have any interest in the state of residence are highly unlikely to participate in political life there, Bauböck's contribution struggles hard with a non-existent problem. He does his best to justify the state-mandated selection of those who 'have the ties' profoundly mistrusting those who actually feel sufficiently affected to demonstrate that politically. As if the ties depended on state-mandated blessings! It seems that only the 'official' certificates are meaningful, not the actual reality they are summoned to certify,

1 See Kochenov, D. (2011), 'Mevrouw de Jong Gaat Eten: EU Citizenship and the Culture of Prejudice', Robert Schuman Centre for Advanced Studies, EUDO Citizenship Observatory Working Paper 2011/06, Florence: European University Institute, available at http://cadmus.eui.eu/handle/1814/15774. 
reminding me of the absurd official documents issued to a pityful little man struck by devilish magic by the cat Behemoth in Bulgakov's The Master and Margarita in testimony of attendance of a witches' shabash in a pig form as a means of aereal transportation. Differently from Bulgakov's hellish world of Stalinist Moscow, the EU has been built specifically to curtail states' ability to improve 'their' peoples' lives at the expense of those across the border. Questions such as 'Should a Polish worker be deported from the UK to free a place for a Scot?' have been answered with the interests of all in mind, against state thinking or nationalist visions.

\section{I.}

From the very first steps of European integration it was clear that the consequences of the European project for the states participating in it will be farreaching. Whether we like it or not, supranationalism and the voluntary conferral of competences by member states to the EU have led to profound changes of the legal-political landscape in Europe. Even if the references to la fédération européenne in the 1950 Schuman Declaration are ignored, the initial goals of the project are undisputed. They included a trade off in which some sovereign powers were exchanged for closer interconnectedness and peace. At the heart of the project lay the idea of putting a limit to what states can do.

While this logic is probably uncontroversial in the areas where competences have been expressly conferred on the Union, such as the customs union, the same rationale also affects areas which are not under the control of the supranational institutions. This is as natural as it was predictable from the very beginning, since the core of the notion of the Internal Market on which the contemporary Union is built is teleological in nature. The supranational institutional structure was put in place to enable the achievement of the Union's goals, thus putting the teleological rationale at the core of the whole construct, as Judge Pescatore has explained forty years $\mathrm{ago}^{2}$. A duty to help and not to hinder supranational integration made its way into the text in the form of the principle of Union loyalty. Consequently, any national law at any level, no matter whether it is generally within the exclusive competence of the member states or not, can be squashed, should it stand in the way of achievement of the goals of the Union interpreted teleologically.

\section{II.}

To expect that profound self-imposed limitations which the member states took up when designing and ratifying the Treaties would not have any consequences outside of the legal field is naïve as much as short-sighted. Legal

2 Miscellanea W.J. Ganshof van der Meersch (1972), Vol. 2, 325. Brussels:

Bruylant. 
change is responsible for social change. That the two are connected is hardly surprising. In fact, this is a testimony to the success of the legal-political endeavour in the first place.

The fact that French men and women cannot imagine a war with Germany is a great sign of the EU's achievements. This is just the tip of the iceberg of change that the EU has brought into state behaviour, which has direct consequences for what is expected of states in Europe today. According to Philip Allott ${ }^{3}$, we have witnessed a shift from diplomacy (using all the available means to promote the states' 'own people's' well-being in interaction with others) to democracy (taking the interests of all into account) in inter-state relations in Europe. In other words, selfishness and inward-looking construction of the state at the expense of others, putting the interests of states' 'own people' above everything, gave way to the awareness of the interests and expectations of others. For concrete people the effects of these developments are as important as they are for the states these people inhabit. The fundamental shift from diplomacy to democracy means that favouring 'your own' is prohibited in the majority of cases: a Scot is not and cannot be better in the eyes of the British government than a Slovak. While implementation problems are well-known, the starting point is nevertheless clear. In the words of Gareth Davies ${ }^{4}$, Article 18 TFEU prohibiting discrimination on grounds of nationality between EU citizens has largely abolished the nationalities of the member states within the scope of application of EU law. Even more, by granting EU citizens free movement rights, the Treaties de facto and also de jure made it largely impossible for the member states to have any 'immigration' policy concerning EU citizens. In other words, modern EU states cannot give preference to their own nationals compared with other EU citizens and are not entitled to stand in the way of EU citizens exercising their Treaty rights. This means that from container societies of destiny (which is a synonym for the lack of individual choice) the member states have turned into spaces for the expression of free will. EU law grants the majority of EU citizens a right to be welcomed where they think they will feel at home and the Court of Justice of the European Union is ready to step in to protect such rights by defending EU citizens in their supranational capacity against member states' claims. This is a bitter pill for nationalists to swallow. Their nationality, however much glorified in primary school education, means much less in the EU context than it would in a world where there is no Union in Europe. This is one of EU's main achievements.

3 Allott, P. (1991), 'The European Community Is not the True European Community', The Yale Law Journal 100 (8): 2485.

4 Davies, G. (2005), “"Any Place I Hang My Hat?” or: Residence is the New Nationality', European Law Journal 11 (1): 55. 


\section{III.}

The fusion of legal and social dynamics described above is responsible for the peculiarities of European states today, compared with other nations around the world. Although no one would dispute the sovereignty of EU member states, it is abundantly clear that their practical functioning in all the fields they could possibly aspire to influence is profoundly affected by the new socio-legal reality of European integration. This is best illustrated by the interrelation between European states and their 'peoples'. EU member states have been transformed from units of destiny into units of choice and are obliged by law to respect all those willing to leave forever and move to a different member state. Many harbour now large numbers of individuals who, although they do not possess the local nationality, cannot be stopped at the border, sent away, or treated worse than the locals. These are the EU citizens, i.e. the non-nationals who are non-foreigners.

The developments described above are fundamental. Once destiny stops obscuring the view, responsibility and freedom come into sight. This responsibility and this freedom affect the essence of what the 'peoples' of the member states are. Crucially, unlike the absolute majority of states outside the EU, member states of the EU cannot shape social facts related to EU citizens' movements. In other words, from the shapers and custodians of 'their' societies, as in Micronesia where those who are not 'ethnic Micronesians' are not entitled to anything, or in Quebec where those who speak French are more welcome, the member states have become mere observes of how EU citizens use EU law and their free will when crossing the ephemeral borders in order to organise their lives as they see fit. The strongest appeal of EU member states in the eyes of mobile EU citizens is their relative invisibility - they do not intrude into the lives of EU citizens choosing to settle outside their member state of nationality.

Why is this transformation important? It seems that it has profound implications for the moral reasons of accepting or rejecting social facts in framing policy and law. States actively involved in shaping immigration policy not only help the societies they serve. They also shape these societies by not letting some people in or mistreating others. Consequently, once it is known that they have this capacity, legitimate pretexts can be listed for not including some permanent residents into the notion of the 'people', such as 'illegal' Latinos in the US or, until very recently, aboriginals in Australia. Does the same hold for the states which are merely entitled to observe as those who chose them come and go? Once the ability to shape the society is lost thanks to the freedom guaranteed by supranational law invocable against the member states, the member states are bound to face substantial difficulties 
in defining the 'people' convincingly, should they have restrictions in mind. This goes far beyond municipal or EP elections, which the EU Treaties open up for all EU citizens. It goes to the very core of the relationship between the people and the state. The state sanction is not required for any EU citizen to belong de facto, and in many respects also de jure, to the people of a member state.

Alongside with a handful of exceptions from the main non-discrimination rule, which are irrelevant for the absolute majority of EU citizens, national elections fall outside the realm of EU law. This is impossible to justify in the light of the developments described above. Once the member states, acting via the EU, have effectively transformed themselves from the shapers of society into the observers of how EU citizens use their rights, the exclusion of EU citizens without a local nationality from national elections becomes unjustifiable, as this boils down to ignoring social facts beyond the states' control. This is exactly why Bauböck's position is unfounded. It adopts a national model in ignoring social facts as a starting point. Since member state nationalities are in the absolute majority of cases legally inconsequential for EU citizens travelling around the EU, connecting democratic participation with naturalisation amounts to artificially inflating the importance of an 'abolished' status.

While it is always easier to argue for not changing anything, in this particular case change is definitely required. Although practically speaking the impact of the initiative, should it be successful, is likely to be very limited, symbolically its significance will be huge.

Open Access This chapter is licensed under the terms of the Creative Commons Attribution 4.0 International License (http://creativecommons.org/licenses/by/4.0/), which permits use, sharing, adaptation, distribution and reproduction in any medium or format, as long as you give appropriate credit to the original author(s) and the source, provide a link to the Creative Commons license and indicate if changes were made.

The images or other third party material in this chapter are included in the chapter's Creative Commons license, unless indicated otherwise in a credit line to the material. If material is not included in the chapter's Creative Commons license and your intended use is not permitted by statutory regulation or exceeds the permitted use, you will need to obtain permission directly from the copyright holder. 